\title{
Adsorption of Organophosphorous Pesticide from Aqueous Solution Using "Waste" Jute Fiber Carbon
}

\author{
S.Senthilkumaar (Corresponding author) \\ Department of Chemistry, PSG College of Technology, Coimbatore, India \\ Tel: 91-422-434-4777 E-mail: sskumaarchem@rediffmail.com
}

S.K. Krishna

Department of Chemistry, MPNMJ Engineering College, Erode, India

P. Kalaamani

Department of Chemistry, NGM College, Pollachi, India

\author{
C. V. Subburamaan
}

School of Environmental Sciences, Bharathiar University, Coimbatore, India

N. Ganapathi Subramaniam

Quantum Functional Semiconductor Research Centre (QSRC), Dongguk University-Seoul

Seoul, South Korea

\begin{abstract}
"Waste" Jute Fiber, an agricultural "waste" by-product was converted into an effective adsorbent and the same was tested for the removal of Malathion pesticide from aqueous solution. The prepared activated Jute fiber carbon (JFC) was characterized by using Scanning Electron microscope (SEM), X-ray diffractometer (XRD), Elemental analyzer and proximate analysis methods. Adsorption equilibrium, kinetics, thermodynamics and mass transfer studies were investigated as a function of agitation time, adsorbent dose, $\mathrm{pH}$ and temperature. The adsorption data obtained are found to obey Langmuir isotherm model. The adsorption kinetics was analyzed by using pseudo first order, pseudo second order and Elovich models. Thermodynamic parameters of adsorption process, i.e. $\Delta \mathrm{G}, \Delta \mathrm{S}$ and $\Delta \mathrm{H}$ were computed and their negative values indicate the adsorption was exothermic and spontaneous nature.
\end{abstract}

Keywords: Malathion, "Waste” Jute fiber carbon, Kinetics, Thermodynamics, Diffusion

\section{Introduction}

Once pesticides are introduced into the environment, whether by application, disposal, or a spill, it can be influenced by many processes. These processes determine the ultimate fate of the pesticide by affecting its persistence and movement in the environment. The developed countries have banned many of the pesticides due to their potential toxic effects to man and ecosystem. In many developing countries, the pesticides use is not being properly regulated leading to residues in food which poses health hazards to the consumers (Khan et al 2009). Developing countries can not stop the usage of certain pesticides due to the cost and efficiency.

China is the world's largest producers of vegetables followed by India. Vegetables are susceptible to insect and disease attacks and pesticides are used widely. Therefore, residues of pesticides could affect the ultimate consumer's health especially when freshly consumed. Many studies reported that the main pesticide residues were organophosphate (Bai et al 2006, Dalal et al 2006 and Shen et al 2002). Organophosphorous pesticides (OPPs) are a group of highly toxic agricultural chemicals widely used in plant protection. Common members of the family are methylparathion, malathion, dimethoate, phosphamidon, phorate, fenitrothion and monocrotophos.

Malathion is a nonsystemic, wide-spectrum organophosphorous pesticide. Malathion is suited for the control of sucking and chewing insects on fruits and vegetables, and is also used to control mosquitoes, flies, household insects, animal parasites (Bonner et al 2007). Malathion has also been used to control the Mediterranean fruit fly in Australia (Edwards et al 2007). Malathion itself is of low toxicity; however, absorption or ingestion into the human body readily results in its metabolism to malaxon, which is substantially more toxic. The effects of 
long-term exposure to oral ingestion of malaoxon in rats, malaoxon has been shown to be 61 times more toxic than Malathion. In one reported case of Malathion poisoning, an infant exhibited severe signs of cholinesterase inhibition after exposure to an aerosol bomb containing 0.5\% Malathion (Gosselin et al 1984). Malathion is toxic and carcinogenic in nature (Pal \& Vanjara, 2001).

Malathion is of low persistence in soil with reported field half-lives of 1 to 25 days (Wauchope et al 1992). Degradation in soil is rapid and related to the degree of soil binding.Breakdown occurs by a combination of biological degradation and nonbiological reaction with water. If released to the atmosphere, Malathion will break down rapidly in sunlight, with a reported half-life in air of about 1.5 days (Howard, 1991).

Hence, the removal of Malathion from water is one of the major environmental concerns. Many studies dealing with the removal of pesticides from soil have been reported (Kopytko et al 2002), relatively few works have reported on the removal of high concentration of pesticides from water (Bandala et al 2006). Several methods are available for pesticide removal such as solid-phase extraction (Souza and Lancas, 2003), photocatalysis (Franco-garcia et al 1996), photo-fenton (Fallmann et al 1999), flocculation (Thebault et al 1981), ion-exchance (Varhney et al 1996), chlorination and ozonisation (Mason et al 1999) and adsorption.

An increasing attention has been focused on adsorption technique due to their efficiency in the removal of pollutant from aqueous solution (Chatterjee et al 2010; Aksu and Kabasakal, 2006; Ru et al 2007; Qiu et al 2009; Cruz et al 2007 and Cruz et al 2008). A larger number of cheaper materials including industrial and agricultural waste have been used to remove different pesticides from the aqueous solution for their safe disposal in to the environment. Activated carbon is one of the most widely used materials for the removal of organic pollutant. These includes tea leves (Islam et al 2009), biomass (Chatterjee et al 2010), chickpea husk (Akhtar et al 2009), olive stones (Bakouri et al 2009a), cotton stalk (Zheng et al 2009), rice bran, rice husk, baggasse fly ash (Akhtar et al 2009 and Gupta et al 2002), date stone(Hameed et al 2009 and Bakouri et al 2009b), biowaste(Senthilkumaar et al 2000), coconut tree male flower(Senthilkumaar et al 2006a and Senthilkumaar et al 2006b), and Jute fiber(Senthilkumaar et al 2006a and Senthilkumaar et al 2005). In this study, we prepared sulphuric acid activated "Waste" jute fiber carbon (JFC) was used as a low-cost material for the removal of Malathion from aqueous solution. Recently, "waste" jute fiber carbon (JFC) successfully used by our research group for the dye removal (Senthilkumaar et al 2005).

\section{Experimental Methods and Materials}

\subsection{Adsorbate}

Technical grade Malathion of $95 \%$ purity (CAS No.: 121-75-5) was used as such without further purification. The structure is given as follows:

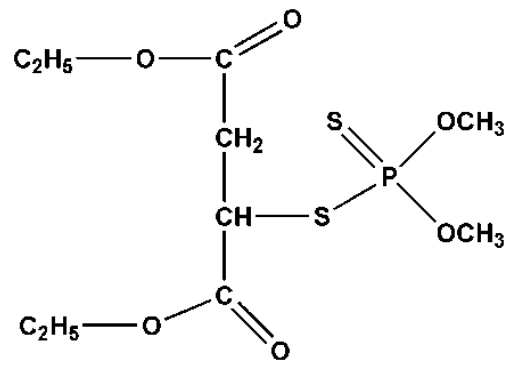

\subsection{JFC-Preparation}

Sun dried "waste" Jute Fiber (JF) was carbonized using sulphuric acid (SA) in the weight ratio 4:3 (JF: SA) and kept in hot air oven, maintained at $160^{\circ} \mathrm{C}$ for a period of $12 \mathrm{~h}$. The carbon was then dried for $4 \mathrm{~h}$ at $100^{\circ} \mathrm{C}$. The resulting carbons were washed with distilled water until a constant $\mathrm{pH}$ of the slurry. The dried materials were ground and sieved to different geometrical sizes and labeled as JFC.

\subsection{Characterization of carbon}

The morphology of "Waste" JFC was evaluated using Scanning Electron microscopy [JEOL, JSM 6360] and found to be irregular pores with different shapes. The amorphous nature of the "Waste" JFC was confirmed using powder XRD patterns [Shimadzu XRD 6000 diffractometer] (figures not given).

Carbon/hydrogen/ oxygen / nitrogen/sulfur (C/H/O/N/S) contents of our carbon were analyzed by using elemental analyzer (model CHNO-RAPID, Heraeus Co., Germany). For each analysis, the standard sample was first analyzed for checking the experimental error. All measurements were carried out in duplicate. The results 
are given in Table 1a.The proximate analysis was made according to ASTM 3172-3175 standards and the results are given in Table $1 \mathrm{~b}$.

\subsection{Adsorption Equilibrium Studies}

In a typical batch studies, fifty milliliters of different initial malathion concentrations $(10,20,30$ and 40mg/L) were taken in a $100 \mathrm{ml}$ conical flasks containing $0.025 \mathrm{~g}$ of "waste" jute fiber carbon (JFC). The flasks were agitated at room temperature $\left(28^{\circ} \mathrm{C}\right)$ at $120 \mathrm{rpm}$ for a pre-determined time intervals using thermostatic rotary orbital shaker with an initial $\mathrm{pH}$ 6.57. At time $\mathrm{t}=0$ and equilibrium, the concentration of malathion was measured using Shimadzu UV - VIS Spectrophotometer (Shimadzu Model: UV 1601). The maximum absorbance of pesticide was read at $193.5 \mathrm{~nm}$ and it was used to calculate the amount of pesticide adsorbed, $\mathrm{q}$ $(\mathrm{mg} / \mathrm{g})$. The adsorption values were measured before and after treatment at their respective adsorption maximum wavelength, and were used to calculate the amount of malathion adsorbed, (q $\mathrm{mg} / \mathrm{g}$ ). For malathion, effect of adsorbent dose was studied by varying carbon dose from 0.20 to $4.5 \mathrm{~g} / \mathrm{L}$ for different malathion concentrations $(10,20,30$ and $40 \mathrm{mg} / \mathrm{L})$. Langmuir isotherm studies were carried out by agitating fixed concentration of JFC, $3 \mathrm{~g} / \mathrm{L}$ of malathion solutions of seven different initial malathion concentrations $60,80,100$, $150,200,250$ and $300 \mathrm{mg} / \mathrm{L}$ for $6 \mathrm{~h}$. For $\mathrm{pH}$ study, fifty milliliters of 20 and $40 \mathrm{mg} / \mathrm{L}$ of malathion solution mixed with $0.025 \mathrm{~g}$ of JFC was agitated at different initial malathion solution $\mathrm{pH}(2-10)$ for $3 \mathrm{~h}$ at $28^{\circ} \mathrm{C}$. Hydrochloric acid and sodium hydroxide solutions were used to regulate the $\mathrm{pH}$. Temperature studies were also carried out with $50 \mathrm{ml}$ of $40-\mathrm{mg} / \mathrm{L}$ malathion solution with the effect of agitation time for four different temperatures $\left(28,33,38\right.$ and $\left.43^{\circ} \mathrm{C}\right)$ to evaluate the effect of temperature on the adsorption process. All the chemicals used are of analytical reagent grade and obtained from Qualigens, Mumbai, India. The used glasswares are of Scott Duran, Germany. In absence of carbon controlled experiments are also carried out for the adsorption of pesticide by the container walls. It was found that there was no detectable degradation or adsorption of pesticide by the container walls.Generally the carbon concentration of $0.5 \mathrm{~g} / \mathrm{L}, \mathrm{pH}$ at 6.57 and room temperature, $28^{\circ} \mathrm{C}$ are maintained in all experiments unless or otherwise stated.

\section{Result and Discussion}

\subsection{Effect of contact time and initial Malathion concentration on adsorption}

Adsorption of malathion onto "Waste" JFC at different concentrations $(10,20,30,40 \mathrm{mg} / \mathrm{L})$ with fixed adsorbent dose $(0.5 \mathrm{~g} / \mathrm{L})$ was carried out at room temperature $\left(28^{\circ} \mathrm{C}\right)$. The flasks were withdrawn at predetermined time intervals and the supernatant was separated physically and centrifuged at $10,000 \mathrm{rpm}$ for 5 min. and analyzed. The effect of pesticide initial concentration with contact time is shown in Figure 1. It is revealed from Figure 1, the percent adsorption decrease with increase in initial malathion concentration. But the actual amount of malathion adsorbed per unit mass of carbon increases with increase in malathion concentration. The unit mass increased from 12.13 to $37.11 \mathrm{mg} / \mathrm{g}$. The equilibrium time was found to be 180,220, 240 and 260 min. for 10, 20, 30 and $40 \mathrm{mg} / \mathrm{L}$ initial concentration of malathion, respectively. The curves in Figure 1 are smooth and continuous, suggesting the possible monolayer coverage of malathion on JFC surface. A similar observation was reported by several researchers for the adsorption of pesticide onto different adsorbents (Akhtar et al 2007; Senthilkumaar et al 2005 and Gupta et al 2001).

\subsection{Effect of adsorbent dose}

The effect of adsorbent dose on the removal of pesticide was studied in the range of $0.2-4.5 \mathrm{~g} / \mathrm{L}$ for different pesticide concentration $(10,20,30$ and $40 \mathrm{mg} / \mathrm{L})$ and are shown in Figure 2. It is seen from Figure 2 that the increase in the concentration of JFC, results in the increase of surface area with more adsorptive sites for the adsorption to occur. Further increase in JFC may not increase the adsorption. This might be due to the interference between binding sites of JFC doses ( Bakouri et al 2009; Akhtar et al 2007; Senthilkumaar et al 2005 and Hamadi et al 2004).

\subsection{Adsorption kinetics}

Different kinetics models are tested in order to explain the adsorption behavior of JFC.

\subsubsection{Pseudo first- order equation}

The Pseudo first- order equation is generally expressed as follows (Lagergren, 1898)

$$
d q_{t} / d_{t}=k_{1}\left(q_{e}-q_{t}\right)
$$


Where, $\mathrm{k}_{1}$ is the pseudo - first order rate constant. After integration by applying conditions, $\mathrm{q}_{\mathrm{t}}=0$ at $\mathrm{t}=0$ and $\mathrm{q}_{\mathrm{t}}$ $=\mathrm{q}_{\mathrm{t}}$ at $\mathrm{t}=\mathrm{t}$, then Equation 1 becomes

$$
\log \left(q_{e}-q_{t}\right)=\log q_{e}-\left(k_{1} / 2.303\right) \mathrm{t}
$$

Where, $\mathrm{q}_{\mathrm{e}}$ is the amount adsorbed at equilibrium.

\subsubsection{Pseudo second - order equation}

If the rate of adsorption is a second - order mechanism, the pseudo second - order kinetic rate equation 3 is expressed as (Ungarish et al 1991),

$$
\frac{d q_{t}}{d_{t}}=k_{2}\left(q_{e-} q_{t}\right)^{2}
$$

Where, $\mathrm{k}_{2}$ is the pseudo - second order rate constant. On integrating the equation 3

$$
t / q_{t}=\left(1 / k_{2} q_{e}^{2}\right)+\left(1 / q_{e}\right) t
$$

\subsubsection{Elovich model}

The most interesting model to describe the activated carbon adsorption (Low, 1960) is Elovich equation 5,

$$
\frac{d q_{t}}{d_{t}}=a \exp \left(-b q_{t}\right)
$$

Where, $\mathrm{a}$ and $\mathrm{b}$ are constants. The constant ' $\mathrm{a}$ ' is considered as the initial adsorption rate ( $\mathrm{mg} / \mathrm{g} \mathrm{min}) \mathrm{and} \mathrm{b}$ is related to the extent of surface coverage and activation energy for adsorptions $(\mathrm{g} / \mathrm{mg}) .\left(\mathrm{dq}_{\mathrm{t}} / \mathrm{dt}\right) \rightarrow \mathrm{a}$ as $\mathrm{q}_{\mathrm{t}} \rightarrow 0$ and given that $\mathrm{q}_{\mathrm{t}}=0$ at $\mathrm{t}=0$, the integrated form of equation 5 becomes,

$$
q_{t}=(1 / b) \ln \left(t+t_{o}\right)-(1 / b) \ln t_{o}
$$

Where, $\mathrm{t}_{\mathrm{o}}=(1 / \mathrm{ab})$. If $\mathrm{t}>>\mathrm{t}_{\mathrm{o}}$, Equation 6 is simplified as,

$$
q=1 / b \ln a b+1 / b \ln t
$$

Where, $a$ is the initial adsorption rate $(\mathrm{mg} / \mathrm{g})$, and the parameter $\mathrm{b}$ is related to the extent of surface coverage.

\subsubsection{Selection of the kinetic model}

We employed three different kinetic models, the pseudo first order, pseudo second order and Elovich kinetic models. The plots of pseudo first order, pseudo second order and Elovich kinetic models are given in the Figures 3, 4 and 5, respectively, for malathion. To compare the fitness of the model $\mathrm{q}_{\mathrm{e}}$ calculated, correlation coefficient $\mathrm{r}^{2}$ and SSE values are calculated and are listed in Table 2 .The $\mathrm{q}_{\mathrm{e}}$ calculated obtained for pseudo first order kinetic model agree with $\mathrm{q}_{\mathrm{e}}$ experimental than those from pseudo second order kinetic model. The results with the value of $\mathrm{r}^{2}>0.9$ and low SSE show that pseudo first order kinetic model is better for predicting the kinetic process in the experimental conditions than the pseudo second order kinetic model (Hameed et al 2009) calculated from Elovich plot shows the compliance of $q_{e}$ calculated with $q_{e}$ experimental, high $r^{2}$ value $(>0.9)$ and low SSE. Elovich model basically supports chemisorptions (Tseng et al 2003 and Juang et al 1997). Sum of the squares of the errors, SSE are calculated using the expression (Juang et al 1997),

$$
S S E=\sqrt{\sum\left(q_{e} \exp -q_{e} c a l\right)^{2} / N}
$$

Where, $\mathrm{N}$ is the number of data points.

\subsection{Adsorption isotherm}

Langmuir isotherm was applied for adsorption equilibrium (Langmuir, 1916), 


$$
C_{e} / q_{e}=1 / K_{L}+a_{L} / K_{L} C_{e}
$$

Where, $\mathrm{K}_{\mathrm{L}}$ and $\mathrm{a}_{\mathrm{L}}$ are Langmuir constants. Equation 9 can be modified as,

$$
\left(C_{e} / q_{e}\right)=\left(1 / b Q_{o}\right)+\left(C_{e} / Q_{o}\right)
$$

Where, Ce is the equilibrium concentration of the malathion solution $(\mathrm{mg} / \mathrm{L})$ at equilibrium, $\mathrm{q}_{\mathrm{e}}$ is the amount of malathion adsorbed at equilibrium $(\mathrm{mg} / \mathrm{g}$ ) and Qo and $\mathrm{b}$ are Langmuir constants related to adsorption capacity and energy of adsorption, respectively. Plotting Ce/qe against Ce, a straight line, have a slope (1/ Qo) and the intercept (1/Qob) is obtained (Figure 6). The essential characteristics of Langmuir equation can be expressed in terms of a dimensionless separation factor $\mathrm{R}_{\mathrm{L}}$ (Hall et al 1966),

$$
R_{L}=1 /\left(1+b C_{o}\right)
$$

Where, Co is the initial malathion concentration $(\mathrm{mg} / \mathrm{L})$. The value $\mathrm{Q}_{0}$, monolayer capacity, b Langmuir constant, $\mathrm{R}^{2}$ correlation coefficient and $\mathrm{R}_{\mathrm{L}}$ dimensionless separation factor values for the concentration of pesticides from 60 to $300 \mathrm{mg} / \mathrm{L}$ are given in the Table 3 The adsorption isotherm assumes that intermolecular forces decreases rapidly with distance and consequently leads to the formation of monolayer of malathion at the surface of the JFC. It also assumes that adsorption takes place at specific sites with in the adsorbent; it is believed that once the adsorbate occupies a site no further adsorption takes place at that site. Adsorption capacity (Qo) was found to be $71.68 \mathrm{mg} / \mathrm{g}$. Calculated $\mathrm{R}_{\mathrm{L}}$ values between 0 and 1 (Table 3) indicated that adsorption of Malathion on JFC was favorable (Akhtar et al 2009 and Senthilkumaar et al 2005).

\subsection{Effect of temperature}

Effect of temperature study was carried out with malathion solution of concentration $40 \mathrm{mg} / \mathrm{L}$ with carbon dose of $0.5 \mathrm{~g} / \mathrm{L}$ for temperature range $28,33,38$ and $43^{\circ} \mathrm{C}$. Amount of malathion adsorbed decreases with the increase in temperature (Figure 7), suggesting the adsorption was exothermic nature. Similar trend on the adsorption of pesticides onto various adsorbents are also reported in the literature (Bakouri et al 2009a; Li et al 2009; Bakouri et al 2009b; Niwas et al 2000 and Gupta et al 2006).

\subsubsection{Thermodynamic parameters}

Thermodynamic parameters, such as $\Delta \mathrm{H}$ and $\Delta \mathrm{S}$ for the adsorption process are also determined using the Eyring's plot,

$$
\ln K_{c}=\Delta S / R-\Delta H \quad / R T
$$

Where, $\mathrm{Kc}=\mathrm{C}_{\mathrm{ad}} / \mathrm{C}_{\mathrm{e}} . \mathrm{Kc}$ is the equilibrium constant of the malathion which is a ratio of $\mathrm{C}_{\mathrm{ad}}$, the concentration of the malathion in the adsorbent and $\mathrm{C}_{\mathrm{e}}$, the concentration of the malathion in the adsorbate. The plot between the values of $\ln \mathrm{Kc}$ and 1/T was presented in Figure 8. From the Figure 8, $\Delta \mathrm{S}$ and $\Delta \mathrm{H}$ values were calculated for the temperatures under investigation $\left(28,33,38\right.$ and $\left.43^{\circ} \mathrm{C}\right)$. Free energy change $(\Delta \mathrm{G})$ was calculated using equation 13 and are presented in Table 4.

$$
\Delta G=\Delta H-T \Delta S
$$

It is revealed from the negative value of $\Delta \mathrm{H}$, the adsorption process is exothermic in nature and the negative value of $\Delta \mathrm{G}$ indicates the spontaneous nature of adsorption. The negative values of $\Delta \mathrm{S}$ shows that an increase in the state of orderness during the adsorption process. This is in agreement with other studies of pesticides adsorption onto various materials (Varhney et al 1996; Bakouri et al 2009a; Li et al 2009; Bakouri et al 2009b; Niwas et al 2000 and Gupta et al 2006).

\subsection{Effect of $p H$}

The adsorption of malathion was studied at different initial $\mathrm{pH}$ values $2-10$ for 20 and $40 \mathrm{mg} / \mathrm{L}$ of malathion with fixed dose of JFC $(0.5 \mathrm{~g} / \mathrm{L})$ at temperature $\left(28^{\circ} \mathrm{C}\right)$. The effect of $\mathrm{pH}$ on the adsorption of malathion is shown in Figure 9.It is seen from Figure 9, the adsorption is favored by more acidic conditions. The attraction forces between malathion and JFC should be high at $\mathrm{pH}$ 3.0. At higher $\mathrm{pH}$ value a portion of surface functional 
groups should become more deprotonated. This makes the weak interaction between the JFC and malathion molecules. Similar results were reported in various adsorption processes (Islam et al 2009; Chatterjee et al 2010 and Akhtar et al 2007).

\subsection{Mass transfer effects}

Kinetic and equilibrium isotherm studies help to identify the mechanism of adsorption process. Prediction of the mechanism is required for designing batch adsorber. According to Weber and Morris (1963), an intraparticle diffusion coefficient $\mathrm{K}_{\mathrm{id}}$ is given by the equation 14 ,

$$
\mathrm{q}_{\mathrm{t}}=\mathrm{K}_{\mathrm{id}} \mathrm{t}^{1 / 2}+\mathrm{C}
$$

The plot of qt vs. $\mathrm{t}^{1 / 2}$ is shown in Figure10. The two regions in Figure 10, suggest that the adsorption process proceeds by surface adsorption and intraparticle diffusion. The initial curved portion of the plot indicates a boundary layer effect, while the second linear portion is due to intraparticle or pore diffusion. The slope of the second linear portion of the plot has been defined to yield the intraparticle diffusion parameter $\mathrm{K}_{\mathrm{id}}$. On the other hand, the intercept of the plot reflects the boundary layer effect. The calculated intraparticle diffusion rate constant, $\mathrm{K}_{\mathrm{id}}$ values are listed in Table 5. The value of $\mathrm{R}^{2}>0.9$ in this model justifies the mechanism for the diffusion of pesticides. In order to determine the actual rate-controlling step involved in the malathion adsorption process, the adsorption data were further analyzed using the kinetic expression given by Boyd et al (1947), This is in accordance with the observations of Reichenberg (1953),

$$
\begin{gathered}
F=1-6 / \pi^{2} \sum_{t}^{\infty}\left(1 / n^{2}\right) \exp -n^{2} B t \\
F=\frac{Q_{t}}{Q_{\infty}} \\
B t=\frac{\pi^{2} D_{i}}{\left(r_{o}\right)^{2}}=\text { time constant }
\end{gathered}
$$

where $\mathrm{F}$ is the fraction of solute adsorbed at different times $\mathrm{t}$ and $\mathrm{Bt}$ is a mathematical function of $\mathrm{F}, \mathrm{D}_{\mathrm{i}}$ is the effective diffusion coefficient of adsorbates in adsorbent phase, $r_{o}$ is the radius of adsorbent particle assumed to be spherical, $\mathrm{Q}_{\mathrm{t}}$ and $\mathrm{Q}_{\infty}$ represent the amount adsorbed $(\mathrm{mol} / \mathrm{g})$ at any time $\mathrm{t}$ and at infinite time.

For every calculated value of $F$, corresponding values of $B_{t}$ are obtained from Reichenberg table (Reichenberg, 1953). The values of $\mathrm{Di}$ are calculated using Equation16, the values of $B_{t}$ and $D_{i}$ are given in the Table 6 . Boyd considered "two kinds of diffusion processes, "particle diffusion" and "film diffusion." The linearity test of $B_{t}$ versus time plots was employed to distinguish between the film diffusion- and particle-diffusion-controlled adsorption with the change in concentration and temperature. If the plot of $\mathrm{B}_{\mathrm{t}} \mathrm{vs}$ time is a straight line passing through the origin, then the adsorption rate is governed by the particle diffusion mechanism; otherwise, it is governed by film diffusion [Helfferich, 1962; Gupta and Ali, 2001). In Figure11 and 12, the plots do not pass through the origin indicating film diffusion nature of malathion with the variation in concentration as well as temperature. Since the adsorption of malathion onto JFC is an exothermic process, the value of $\mathrm{D}_{\mathrm{i}}$ decreases with the rise of temperature.

\section{Conclusion}

The adsorption of the pesticide was carried with "Waste" Jute Fiber Carbon as an adsorbent. The adsorption increases with increase in malathion concentration. From the effect of JFC dose study, adsorption increases with increase of JFC dose up to the equilibrium. The adsorption follows first order kinetics supported by Elovich model. The adsorption isotherm data were well described by Langmuir adsorption isotherm model. The adsorption process was found to be exothermic in nature. The thermodynamic study reveals, the adsorption process shows a negative value of $\Delta \mathrm{G}$, indicating the exothermic nature of adsorption; the negative value of $\Delta \mathrm{S}$ values, suggesting a spontaneous pesticide adsorption process; negative $\Delta \mathrm{H}$, indicate an increase in the state of orderness during adsorption. On increasing the $\mathrm{pH}$ of malathion solution, it is found that the adsorption rate decreases. The film diffusion mechanism was confirmed by mass transfer study.

\section{References}

Akhtar, M., Iqbal, S., Bhanger, M. I., Zia-Ul-haq, M., \& Moazzam, M. (2009). Sorption of organophosphorous pesticides onto Chickpea husk from aqueous solutions. Colloids and Surfaces, B: Biointerfaces, 69, 63-70. 
Aksu, Z., \& Kabasakal, E. (2007). Adsorption Characteristics of 2, 4- Dichlorophenoxyacetic acid (2, 4-D) from aqueous solution on powered activated carbon. Journal of Environmental Science and Health, Part B, 40, 545570

Bai, Y. H., Zhou, L., \& Wang, J. (2006). Organophosphorous pesticides residues in market foods in Shaanxi area, China. Food Chemistry, 98, 240-242.

Bakouri, H. EI., Usero, J., Morillo, J., Rojas, R., \& Ouassini, A. (2009b). Drin pesticides removal from aqueous solutions using acid-treated date stones. Bioresource Technology, 100, 2676- 2684.

Bandala, E. R., Octaviano, J. A., Pastrana, P., \& Torres, L. G. (2006). Removal of aldrin, dieldrin, heptachlor, and heptachlor epoxide and/or pseudomonas fluorescens free cell cultures. Journal of Environmental Science and Health, Part B, 4, 1553-569.

Bonner, M. R., Coble, J., \& Blair, A. (2007). Malathion exposure and the incidence of cancer in the agricultural health study. American Journal of Epidemiology, 166, 1023.

Boyd, G. E., Adanson, A.W., \& Mayers, L. S. (1947). The exchange adsorption of ions from aqueous solution by organic zeolites. II kinetics. Journal of the American Chemical Society, 69, 2836.

Chatterjee, S., Das, S. K., Chakravarty, R., Chakrabarti, A., Ghosh, S., \& Guha, A. K. (2010), Interaction of malathion, an organophosphorus pesticide with Rhizopus oryzae biomass. Journal of Hazardous Materials, 174 (1-3), 47-53.

Cruz, M. S. R., Andrades, M. S., Parada, A. M., \& Martin, M. J. S. (2008). Effect of different wood pretreatment on the sorption- desorption of Linuron and Metalaxyl by woods. Journal of Agricultural and Food Chemistry, 56, 7339-7346.

Cruz, S. R., Andrades, M. S., Camazano, M. S., \& Martin, M. J. S. (2007). Relation between the adsorption capacity of pesticides by wood residues and the properties of woods and pesticides. Environmental Science \& Technology, 41, 3613-3619.

Dalal, M., Dani, R. G., \& Kumar, P. A. (2006). Current trends in the genetic engineering of vegetables crops. Scientia Horticulyuria, 107, 215-225.

Edwards, J. W., Lee, S. G., Heath, L. M., \& Pisaniello, D. L. (2007). Worker exposure and a risk assessment of malathion and fenthion used in the control of mediterranean fruit fly in south australia. Environmental Research, $103(1), 38-45$.

Fallmann, H., Krutzler, T., Bauer, R., Malato, S., \& Blanco, J. (1999). Applicability of the Photo- Fenton method for treating water containing pesticides. Catalysis Today, 54, 309-319.

Franco-garcia, M. L., Murat, M., Percherancier, J. P., \& Pouyet, B. (1996). Investigation of aqueous adsorption desorption of pesticide on $\mathrm{sio}_{2}$. Fresenius Environmental Bulletin, 5, 563-568.

Gosselin, R. E., Smith, R. P., \& Hodge, H. C. (1984). Clinical Toxicology of Commercial Products. (5 ${ }^{\text {th }}$ ed.). (pp.5-45). Williams and Wilkins, Baltimore, MD.

Gupta, V. K., \& Ali, I. (2001). Removal of DDD and DDE from wastewater using bagasse fly ash, a sugar industry waste. Water Research, 35, 33-40.

Gupta, V. K., Ali, I., Suhas, \& Saini, V.K. (2006). Adsorption of 2, 4-D and carbofuran pesticides using fertilizer and steel industry wastes. Journal of Colloid and Interface Science. 299, 556-563.

Hall, K. R., Eagleton, L. C., Acrivos, A, \& Vermeulen, T. (1966). Pore-and solid-diffusion kinetics in fixed-bed adsorption under constant-pattern conditions. Industrial \& Engineering Chemistry Fundamentals, 5, 212-223.

Hamadi, N. K., Swaminathan, S., \& Chen, X. D. (2004). Adsorption of paraquat dichloride from aqueous solution by activated carbon derived from used tires. Journal of Hazardous Materials B, 122, 133-141.

Hameed, B. H., Salman, J. M., \& Ahmad, A. L. (2009). Adsorption isotherm and kineti modeling of 2, 4-D pesticide on activated carbon derived from date stones. Journal of Hazardous Materials, 163, 121-126.

Helfferich, F. (1962). Ion exchange. New York: McGraw Hill Book Co. Inc.

Hicham E I Bakouri., Jose Usero., Jose Morilla., Abdelhamid., \& Abdelhamid Ouassini, (2009b). Adsorptive features of acid-treated olive stones for Drin pesticides: Equilibrium, Kinetic and thermodynamic modeling studies. Bioresource Technology, 100, 4147-4155. 
Howard, P. H. (1991) Ed. Handbook of Environmental Fate and Exposure Data for Organic Chemicals, Vol. 3 : Pesticides, (pp.5-13), Lewis Publishers, Chelsea, MI.

Islam, M. A., Sakkas, V., Albanis, T. A. (2009). Application of statistical design of experimental with desirability function for the removal of organophosphorous pesticides from aqueous solution by low-cost material. Journal of Hazardous Materials, 170 (1), 230-238.

Juang, R. S., \& Chen, M. L. (1997). Application of the Elovich equation to the kinetics of metal sorption with solvent - impregnated resins. Industrial and Engineering chemistry research, 36, 813 - 820.

Khan, B. A., Farid, A., Asi, M. R., Shah, H., \& Badshah, A. K. (2009). Determination of residues of trichlorfon and dimethoate on guava using HPLC. Food Chemistry, 114, 286-288.

Kopytko, M., Chalela, G., \& Zaucher, F. (2002). Biodegradation of two commercial herbicides Gramoxone and Matancha) by the bacteria Pseudomonas putida. Electronic Journal of Biotechnology, 5, 182-195.

Kunquan Li., Zheng Zheng., Jingwei Feng., Jibiao Zhang., \& Xingzhang Luo. (2009). Adsorption of p-nitroaniline from aqueous solutions onto activated carbon fiber prepared from cotton stalk. Journal of Hazardous Materials, 166, 1180-1185.

Lagergren, S. (1898). Zur theorie der sogenannten adsorption gelöster stoffe.Kungliga Svenska Vetenskap sakademiens. Handlingar, 24, 1-39.

Langmuir, I. (1916). The constitution and fundamental properties of solids and liquids. Journal of the American Chemical Society, 38, 2221-2295.

Low, M. J. D. (1960). Kinetic modeling of liquid phase adsorption of reactive dyes and metal ions on chitosan. Chemical Reviews, 60, 267-312.

Mason, Y. Z., Choshen, E., \& Rav-Acha, C. (1990). Carbamate insecticides: Removal from water by chlorination and ozonation. Water Research, 24, 11-21.

Mubeena Akhtar., Syed Moosa Hasany., Bhanger, M. I., \& Shahid Iqbal. (2007). Low cost sorbents for the removal of methyl parathion pesticide from aqueous solutions, Chemosphere, 66, 1829-1838.

Niwas, R., Gupta, U., Khan, A. A., \& Varshney, K. G. (2000). The adsorption of phosphamidon on the surface of styrene supported Zirconium (IV) tungstophosphate; a thermodynamic study.Colloids and Surfaces, A: Physicochemical and Engineering Aspects, 164, 115-119.

Pal, O. R., \& Vanjara, A. K. (2001). Removal of malathion and butachlor from a aqueous solution by clays and organoclay. Separation and Purification Technology, 24, 167-172.

Qiu, Y., Xiao, X., Cheng, H., Zhou, Z., \& Sheng, G. D. (2009). Influence of environmenta factors on pesticide adsorption by black carbon: $\mathrm{pH}$ and model dissolved organic matter. Environmental Science \& Technology, 43, 4973-7978

Reichenberg, D. (1953). Properties of ion-exchange resins in relation to their structure. III. Kinetics of exchange. Journal of the American Chemical Society, 75, 589 - 97.

Ru, J., Liu, H. J., Qu, J. H., Wang, A. M., Dai, R. H., \& Wang, Z. J. (2007). Selective removal of organochlorine pesticides (OCPs) from aqueous solution by triolein-embedded composite adsorbent. Journal of Environmental Science and Health, Part B, 42, 53-61.

Ru-ling Tseng., Feng-Chin Wu., \& Ruey-Shin Juang. (2003). Liquid-phase adsorption of dyes and phenols using pinewood-based activated carbons. Carbon, 41, 487-495.

Senthilkumaar, S., Bharathi, S., Nithyanandhi, D., \& Subburaam, C. V. (2000). Biosorption of toxic heavy metals from aqueous solutions. Bioresource Technology, 75, 163-165.

Senthilkumaar, S., Kalaamani, P., Porkodi, K., Varadarajan, P. R., \& Subburaam, C.V (2006a). Adsorption of dissolved reactive red dye from aqueous phase onto activated carbon prepared from agricultural waste Bioresource Technology, 97, 1618-1625.

Senthilkumaar, S., Kalaamani, P., Porkodi, K., Varadarajan, P. R., \& Subburaam, C. V. (2005). Adsorption of methylene blue onto jute fiber carbon: kinetics and equilibrium studies. Journal of Colloid and Interface Science, 284, 78-82.

Senthilkumaar, S., Kalaamani, P., Subburaam, C. V. (2006b). Liquid phase adsorption of crystal violet onto activated carbons derived from male flowers of coconut tree. Journal of Hazardous Materials, 136, 800-808. 
Shen, G. X., Ke, F. Y., \& Zhang, J. Q. (2002). Investigation and evaluation of the contents of pollutants in greenhouse vegetables in Shanghai. Shanghai Environmental Sciences, 21, 475- 477.

Souza, D. A., \& Lancas, F. M. (2003). Solventless sample preparation for pesticides analysis in environmental water samples using solid-phase microextration-high resolution gas chromatography/mass spectrometry. Journal of Environmental Science and Health, Part B Pesticides, Food Contaminants, and Agricultural Wastes, 38, 417-428.

Thebault, P., Cases, J. M., \& Fiessinger. F. (1981). Mechanism underlying the removal of organic micro pollutants diring flocculation by an aluminum or iron salt. Water Research, 15,183-189.

Ungarish, M., \& Aharoni, C. (1991). Kinetics of chemisorption: deducing kinetic laws from experimental data. Journal of the Chemical Society - Faraday Transactions, 77, 975-985.

Varhney, K. G., Khan, A. A., Gupta, U., \& Maheswari, S. M. (1996). Kinetics of adsorption on antimony (v) phosphate cation exchanger: evaluation of the order of reaction and some physical parameters. Colloids and Surfaces, A: Physicochemical and Engineering Aspects, 113, 19-23.

Vinod K. Gupta., Jain C. K., Imran Ali., Chanra., S. \& Agarwal S. (2002). Removal lindane and malathion from wastewater using bagasse fly ash-a sugar industry waste, Water Research, 36, 2483-2490.

Wauchope, R. D., Buttler, T. M., Hornsby A. G., Augustijn-Beckers, P. W. M., \& Burt, J.P. (1992). SCS/ARS/CES Pesticide properties database for environmental decisionmaking. Review of Environmental Contamination Toxicology, 123, 5-20.

Weber, W. J., \& Morris, J. C. (1963). Kinetics of adsorption on carbon solution. Journal of Sanitary Engineering Division-ASCE/ 89, 31-60.

Table 1a. Elemental and Proximate analysis of "Waste" JFC

\begin{tabular}{lr}
\hline Element & Composition (Wt. \%) \\
\hline Carbon & 52.66 \\
Hydrogen & 3.22 \\
Nitrogen & 0.14 \\
Sulfur & 0.98 \\
\hline
\end{tabular}

Table $1 b$.

\begin{tabular}{lr}
\hline Contents & Composition (\%) \\
\hline Moisture & 12.22 \\
Ash & 2.69 \\
Volatile Matter & 61.28 \\
Fixed Carbon & 23.81 \\
& \\
\hline
\end{tabular}


Table 2. Consolidated table for kinetics of Malathion adsorption.

\begin{tabular}{|c|c|c|c|c|c|c|c|c|c|c|c|c|c|}
\hline \multirow{2}{*}{$\begin{array}{l}\text { Con. } \\
\mathrm{mg} \\
/ \mathrm{L}\end{array}$} & \multirow{2}{*}{$\begin{array}{l}\mathrm{q}_{\mathrm{e}} \\
\mathrm{exp} \\
\mathrm{mg} / \\
\mathrm{g}\end{array}$} & \multicolumn{4}{|c|}{ Pseudo first order } & \multicolumn{4}{|c|}{ Pseudo second order } & \multicolumn{4}{|c|}{ Elovich kinetic model } \\
\hline & & $\begin{array}{l}\mathrm{q}_{\mathrm{e}} \mathrm{cal}, \\
\mathrm{mg} / \mathrm{g}\end{array}$ & $\begin{array}{l}\mathrm{k} \\
\mathrm{X} 10^{-2} \\
\mathrm{Min}^{-1}\end{array}$ & $\mathrm{R}^{2}$ & SSE & $\begin{array}{l}\mathrm{q}_{\mathrm{e}} \\
\mathrm{cal}, \\
\mathrm{mg} / \\
\mathrm{g}\end{array}$ & $\begin{array}{l}\mathrm{k} \\
\mathrm{X} 10^{-4} \\
\mathrm{Min}^{-1}\end{array}$ & $\mathrm{R}^{2}$ & SSE & $\begin{array}{l}\mathrm{q}_{\mathrm{e}} \mathrm{cal}, \\
\mathrm{mg} / \mathrm{g}\end{array}$ & $1 / b$ & $\mathrm{R}^{2}$ & SSE \\
\hline 10 & 12.13 & 12.64 & 1.33 & 0.974 & 0.509 & 16.26 & 7.820 & 0.940 & 4.125 & 10.678 & 2.985 & 0.940 & 1.897 \\
\hline 20 & 25.90 & 25.192 & 0.757 & 0.955 & 0.708 & 35.56 & 2.393 & 0.906 & 9.662 & 21.148 & 5.884 & 0.930 & 1.856 \\
\hline 30 & 27.89 & 27.861 & 0.766 & 0.988 & 0.029 & 34.93 & 3.280 & 0.950 & 7.038 & 24.772 & 6.531 & 0.939 & 0.560 \\
\hline 40 & 37.11 & 36.48 & 1.22 & 0.936 & 0.63 & 52.61 & 1.647 & 0.930 & 15.49 & 33.36 & 9.181 & 0.936 & 1.253 \\
\hline
\end{tabular}

Table 3. Langmuir Adsorption isotherm parameters.

\begin{tabular}{|c|c|c|c|c|}
\hline Conc. mg /L & $\mathrm{R}_{\mathrm{L}}$ & $\mathrm{b}(\mathrm{l} / \mathrm{mg})$ & $\begin{array}{c}\mathrm{Q}_{\mathrm{o}} \\
\mathrm{mg} / \mathrm{g}\end{array}$ & $\mathrm{R}^{2}$ \\
\hline 60 & 0.0240 & & & \\
\hline 80 & 0.0177 & & & \\
\hline 100 & 0.0142 & & & \\
\hline 150 & 0.0119 & 0.6934 & 71.68 & 0.9671 \\
\hline 200 & 0.0102 & & & \\
\hline 250 & 0.0089 & & & \\
\hline 300 & 0.0080 & & & \\
\hline
\end{tabular}

Table 4.Thermodynamic data for the Removal of Malathion studied.

\begin{tabular}{|c|c|c|c|c|c|c|c|c|c|}
\hline & $-\Delta G$ & $\mathrm{~K} \mathrm{~J}$ mole & & & & & & $-\Delta \mathrm{S}$ & $-\Delta \mathrm{H}$ \\
\hline $28^{\circ} \mathrm{C}$ & $33^{\circ} \mathrm{C}$ & $38^{\circ} \mathrm{C}$ & $43^{\circ} \mathrm{C}$ & $28^{\circ} \mathrm{C}$ & $33^{\circ} \mathrm{C}$ & $38^{\circ} \mathrm{C}$ & $43^{\circ} \mathrm{C}$ & & \\
\hline 2.74 & 2.519 & 2.298 & 2.077 & 0.865 & 0.763 & 0.697 & 0.659 & 44.212 & 16.048 \\
\hline
\end{tabular}

Table 5. Intraparticle diffusion parameters.

\begin{tabular}{rcccc}
\hline Conc. $\mathrm{mg} / \mathrm{L}$ & $\mathrm{q}_{\mathrm{e}}$ exp. $\mathrm{mg} / \mathrm{g}$ & $\mathrm{q}_{\mathrm{e}}$ cal.mg/g & $\mathrm{K} \mathrm{min}^{-1}$ & $\mathrm{R}^{2}$ \\
\hline 10 & 12.13 & 12.006 & 0.9708 & 0.9868 \\
20 & 25.90 & 24.133 & 1.8073 & 0.9848 \\
30 & 27.89 & 27.374 & 1.9842 & 0.9841 \\
40 & 37.11 & 38.270 & 2.5731 & 0.9847 \\
10 & 12.13 & 12.006 & 0.9708 & 0.9868 \\
\hline
\end{tabular}


Table 6. Diffusion coefficients for the adsorption onto JFC at various concentrations and temperatures

\begin{tabular}{cccccccc}
\hline & \multicolumn{2}{c}{$\begin{array}{c}\text { Diffusion coefficient, } \\
\text { Di x } 10^{-12}, \mathrm{~m}^{2} / \mathrm{sec}\end{array}$} & & \multicolumn{4}{c}{$\begin{array}{c}\text { Diffusion coefficient, } \\
\text { Di x } 10^{-12}, \mathrm{~m}^{2} / \mathrm{sec}\end{array}$} \\
\hline $10 \mathrm{mg} / \mathrm{L}$ & $20 \mathrm{mg} / \mathrm{L}$ & $30 \mathrm{mg} / \mathrm{L}$ & $40 \mathrm{mg} / \mathrm{L}$ & $28^{\circ} \mathrm{C}$ & $38^{\circ} \mathrm{C}$ & $43^{\circ} \mathrm{C}$ & $48^{\circ} \mathrm{C}$ \\
\hline 2.281 & 0.836 & 0.928 & 0.928 & 0.6762 & 0.0108 & 0.0101 & 0.4730 \\
\hline
\end{tabular}

\section{Figure Legends}

Figure1. Effect of contact time and initial malathion concentration. $(\mathrm{O})=10 \mathrm{mg} / \mathrm{L} ;(\Delta)=20 \mathrm{mg} / \mathrm{L} ;(\square)=30$ $\mathrm{mg} / \mathrm{L} ;(\nabla)=40 \mathrm{mg} / \mathrm{L}$. Conditions: Initial $\mathrm{pH}=6.5 ; \mathrm{JFC}$ dose $=0.5 \mathrm{~g} / \mathrm{L} ;$ Temperature $=28^{\circ} \mathrm{C}$.

Figure 2. Effect of adsorbent dose on adsorption of malathion. $(O)=10 \mathrm{mg} / \mathrm{L} ;(\Delta)=20 \mathrm{mg} / \mathrm{L} ;(\square)=30 \mathrm{mg} / \mathrm{L} ;(\nabla)$ $=40 \mathrm{mg} / \mathrm{L}$. Conditions: Initial $\mathrm{pH}=6.5 ; \mathrm{JFC}$ dose $=0.2-4.5 \mathrm{~g} / \mathrm{L}$; Temperature $=28^{\circ} \mathrm{C}$.

Figure 3. Pseudo-first-order kinetic model. $(\mathrm{O})=10 \mathrm{mg} / \mathrm{L} ;(\Delta)=20 \mathrm{mg} / \mathrm{L} ;(\square)=30 \mathrm{mg} / \mathrm{L} ;(\nabla)=40 \mathrm{mg} / \mathrm{L}$. Conditions: Initial $\mathrm{pH}=6.5 ; \mathrm{JFC}$ dose $=0.5 \mathrm{~g} / \mathrm{L}$; Temperature $=28^{\circ} \mathrm{C}$.

Figure 4. Pseudo-second-order kinetic model. $(O)=10 \mathrm{mg} / \mathrm{L} ;(\Delta)=20 \mathrm{mg} / \mathrm{L} ;(\square)=30 \mathrm{mg} / \mathrm{L} ;(\nabla)=40 \mathrm{mg} / \mathrm{L}$. Conditions: Initial $\mathrm{pH}=6.5 ; \mathrm{JFC}$ dose $=0.5 \mathrm{~g} / \mathrm{L}$; Temperature $=28^{\circ} \mathrm{C}$.

Figure 5. Elovich-kinetic model. $(\mathrm{O})=10 \mathrm{mg} / \mathrm{L} ;(\Delta)=20 \mathrm{mg} / \mathrm{L} ;(\square)=30 \mathrm{mg} / \mathrm{L} ;(\nabla)=40 \mathrm{mg} / \mathrm{L}$. Conditions: Initial $\mathrm{pH}=6.5 ; \mathrm{JFC}$ dose $=0.5 \mathrm{~g} / \mathrm{L} ;$ Temperature $=28^{\circ} \mathrm{C}$.

Figure 6. Langmuir isotherm model. Conditions : malathion concentration $=60-300 \mathrm{mg} / \mathrm{L} ; \quad$ Initial $\mathrm{pH}=6.5$; $\mathrm{JFC}$ dose $=3.0 \mathrm{~g} / \mathrm{L}$; Temperature $=28^{\circ} \mathrm{C}$.

Figure 7. Effect of temperature on malathion removal. $(\mathrm{O})=28^{\circ} \mathrm{C} ;(\Delta)=33^{\circ} \mathrm{C} ;(\square)=38^{\circ} \mathrm{C} ;(\nabla)=43^{\circ} \mathrm{C}$ Conditions: malathion concentration $=40 \mathrm{mg} / \mathrm{L}$; Initial $\mathrm{pH}=6.5 ; \mathrm{JFC} \quad$ dose $=0.5 \mathrm{~g} / \mathrm{L}$.

Figure 8. Plot for estimation of thermodynamic parameters for the adsorption of malathion. $(\mathrm{O})=28^{\circ} \mathrm{C} ;(\Delta)=$ $\left.33^{\circ} \mathrm{C} ; \square\right)=38^{\circ} \mathrm{C} ;(\nabla)=43^{\circ} \mathrm{C}$ Conditions; malathion concentration $=40 \mathrm{mg} / \mathrm{L}$; Initial $\mathrm{pH}=6.5 ; \mathrm{JFC}$ dose $=0.5 \mathrm{~g} / \mathrm{L}$.

Figure 9. Effect of initial $\mathrm{pH}$ on malathion removal. $(\mathrm{O})=20 \mathrm{mg} / \mathrm{L} ;(\Delta)=40 \mathrm{mg} / \mathrm{L}$; Conditions: Initial $\mathrm{pH}=6.5$; $\mathrm{JFC}$ dose $=0.5 \mathrm{~g} / \mathrm{L} ;$ Temperature $=28^{\circ} \mathrm{C}$.

Figure 10. Intraparticle diffusion. $(\mathrm{O})=10 \mathrm{mg} / \mathrm{L} ;(\Delta)=20 \mathrm{mg} / \mathrm{L} ;(\square)=30 \mathrm{mg} / \mathrm{L} ;(\nabla)=40 \mathrm{mg} / \mathrm{L}$. Conditions: Initial $\mathrm{pH}=6.5 ; \mathrm{JFC}$ dose $=0.5 \mathrm{~g} / \mathrm{L} ;$ Temperature $=28^{\circ} \mathrm{C}$.

Figure 11. Effect of Concentration of malathion on the Diffusion coefficient. (O) $=10 \mathrm{mg} / \mathrm{L} ;(\Delta)=20 \mathrm{mg} / \mathrm{L} ; \square)$ $=30 \mathrm{mg} / \mathrm{L} ;(\nabla)=40 \mathrm{mg} / \mathrm{L}$. Conditions: Initial $\mathrm{pH}=6.5 ; \mathrm{JFC}$ dose $=0.5 \mathrm{~g} / \mathrm{L} ;$ Temperature $=28^{\circ} \mathrm{C}$.

Figure 12. Effect of Temperature on the Diffusion coefficient of malathion. $(\mathrm{O})=28^{\circ} \mathrm{C} ;(\Delta)=33^{\circ} \mathrm{C} ;(\square)=38^{\circ} \mathrm{C}$; $(\nabla)=43^{\circ} \mathrm{C}$ Conditions: malathion concentration $=40 \mathrm{mg} / \mathrm{L} ;$ Initial $\mathrm{pH}=6.5 ; \mathrm{JFC}$ dose $=0.5 \mathrm{~g} / \mathrm{L}$. 


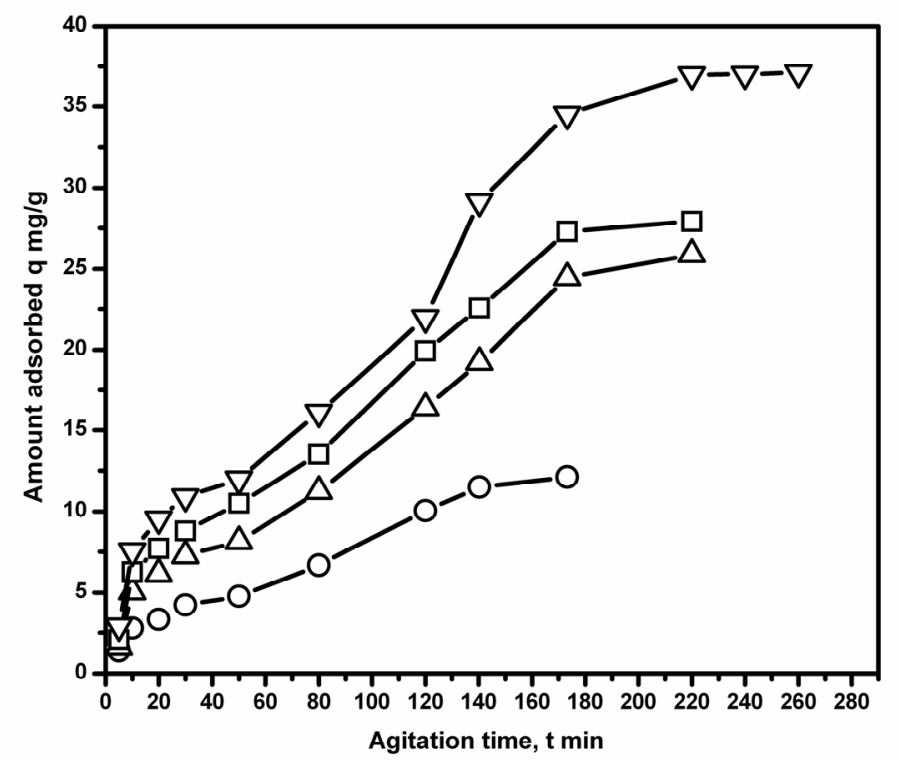

Figure 1. Effect of contact time and initial Malathion concentration.

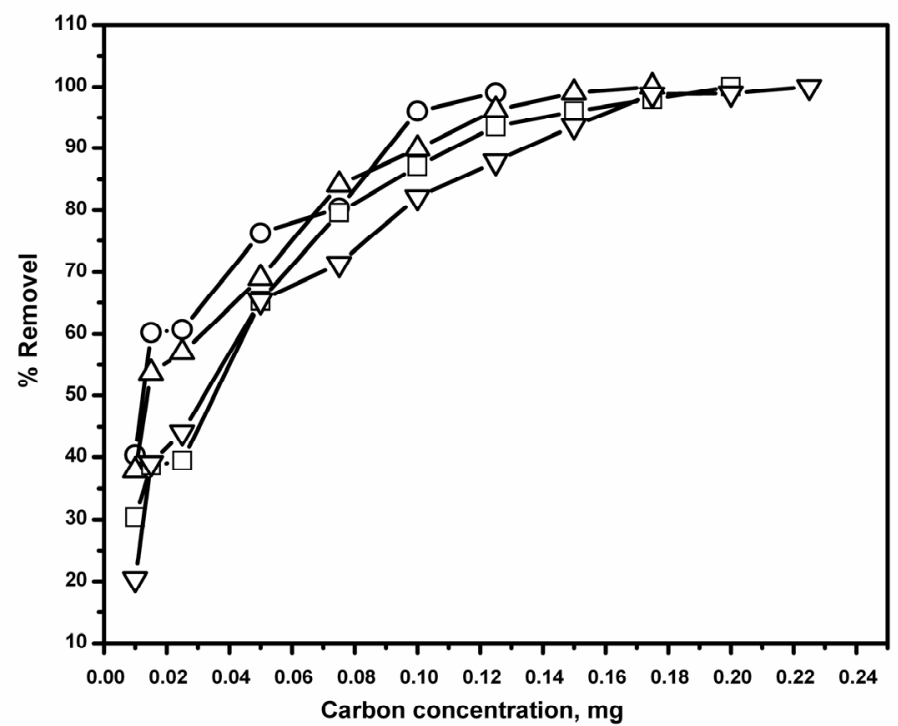

Figure 2. Effect of adsorbent dose on adsorption of Malathion. 


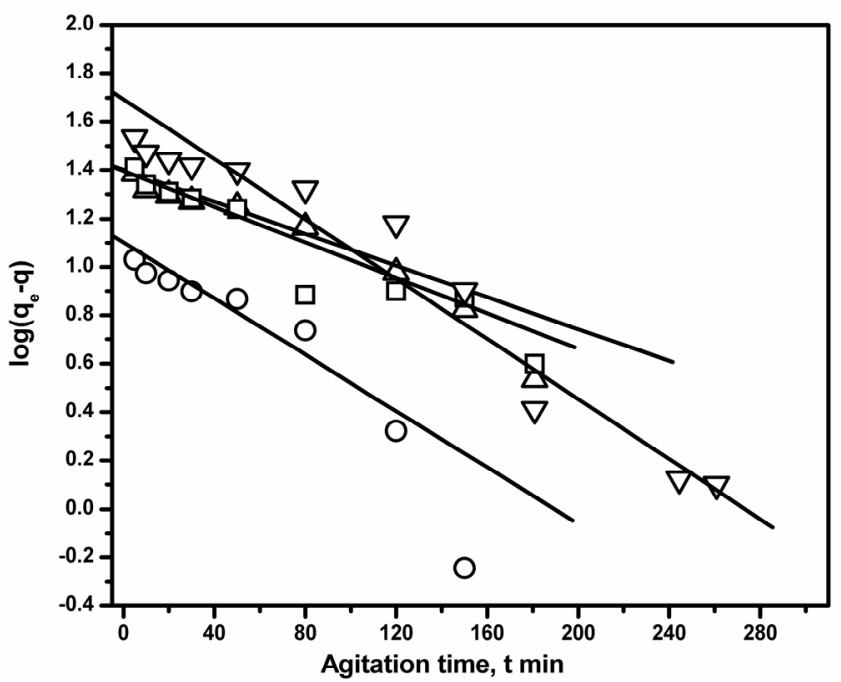

Figure 3. Pseudo-first-order kinetic model.

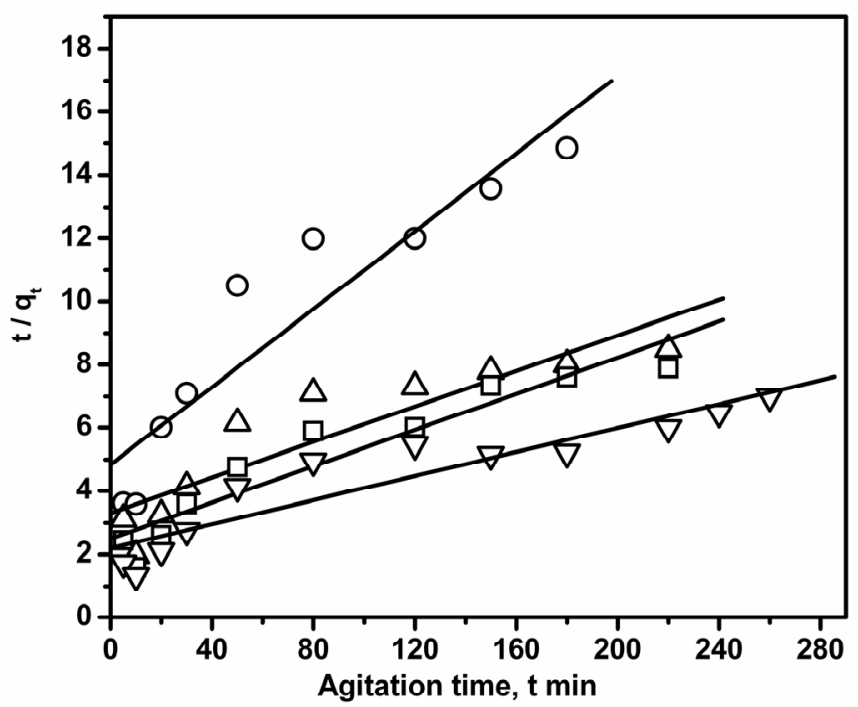

Figure 4. Pseudo-second-order kinetic model. 


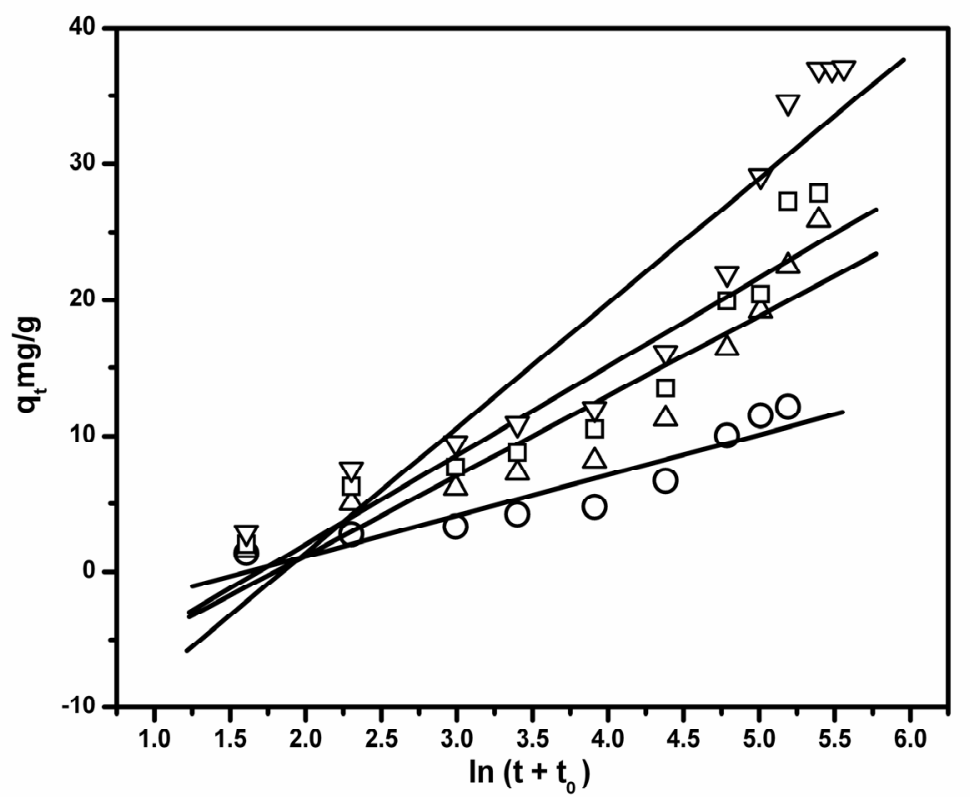

Figure 5. Elovich-kinetic model.

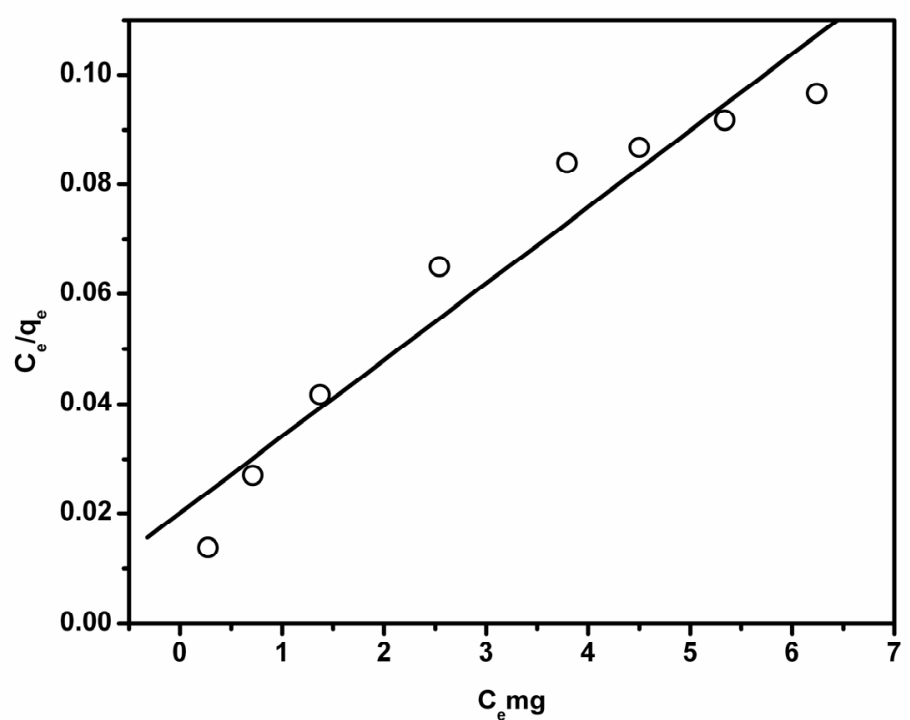

Figure 6. Langmuir isotherm Model. 


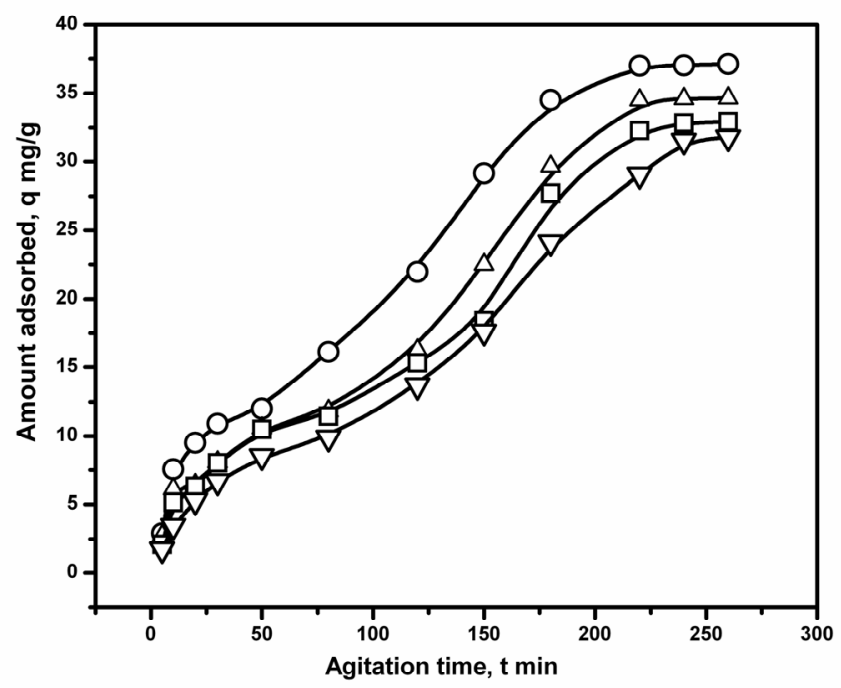

Figure 7. Effect of temperature on Malathion removal.

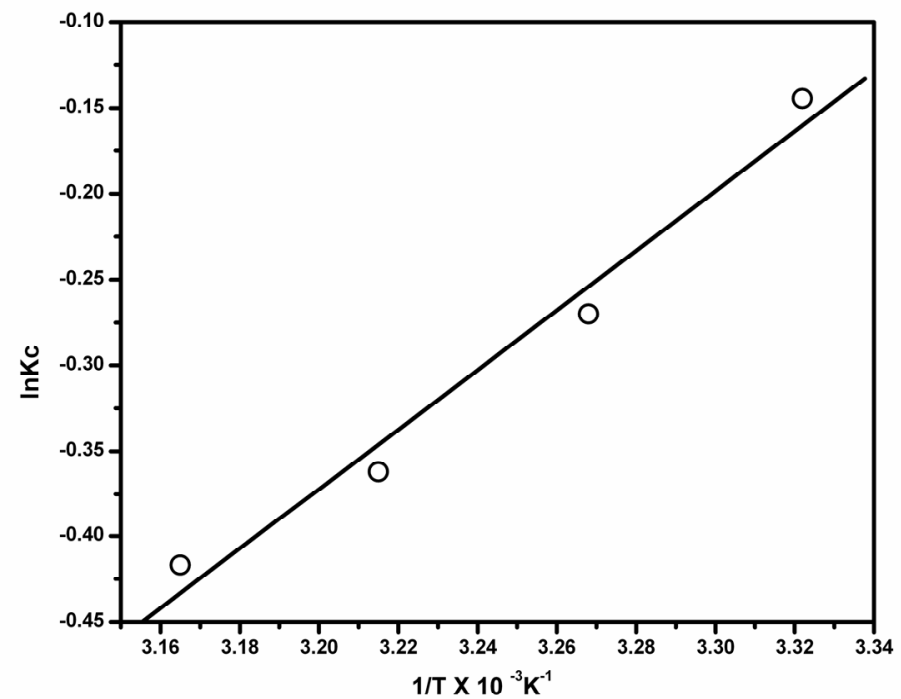

Figure 8. Plot for estimation of thermodynamic parameters for the adsorption of Malathion onto JFC. 


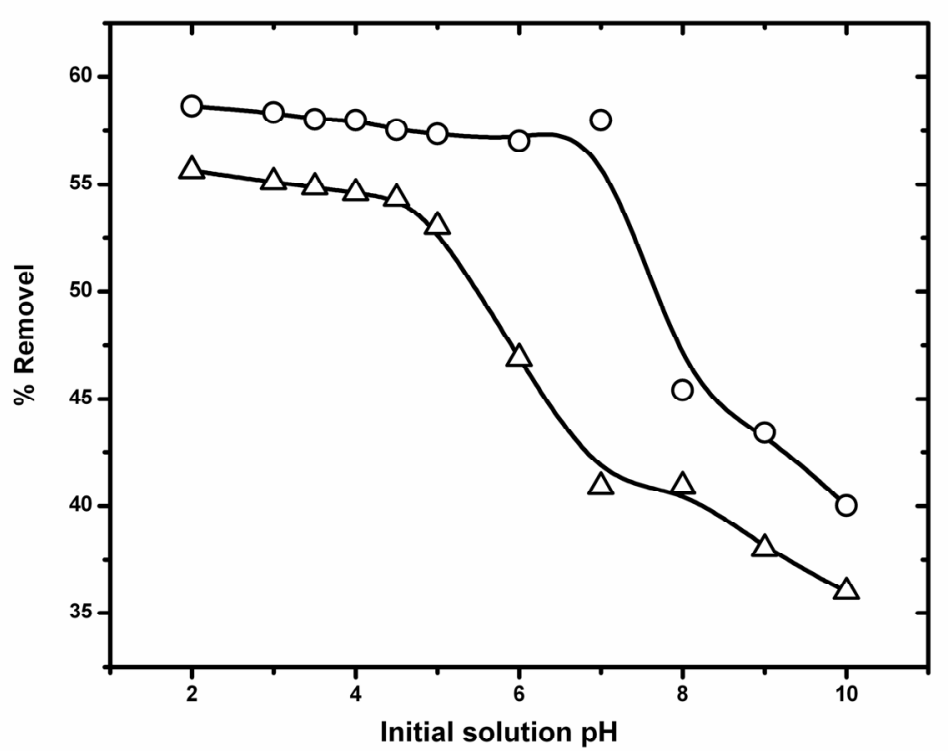

Figure 9. Effect of initial pH on Malathion removal.

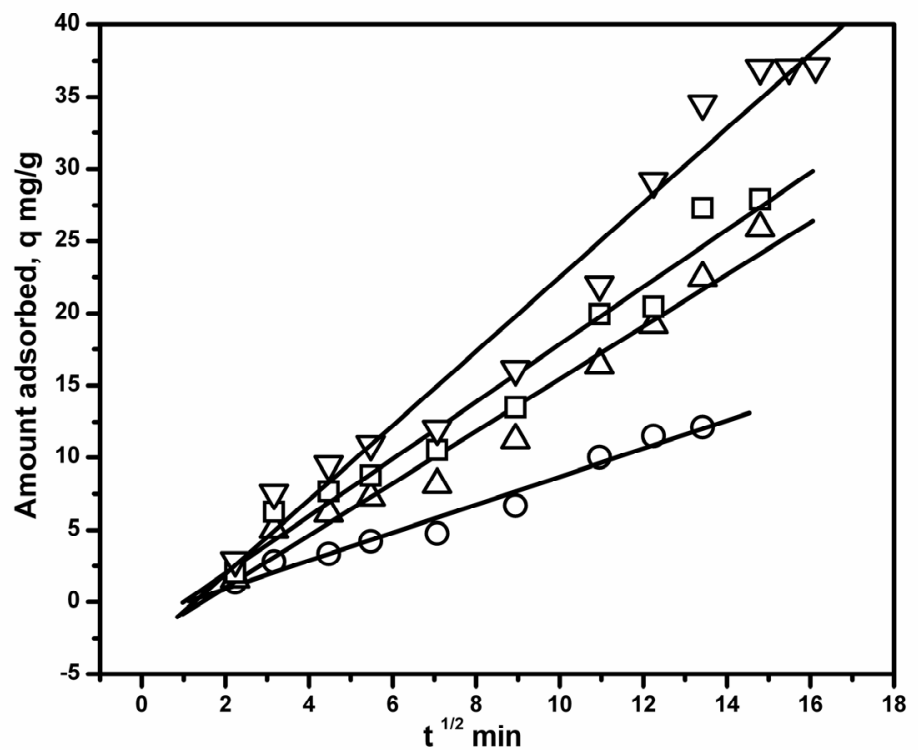

Figure 10. Intraparticle diffusion on Malathion adsorption. 


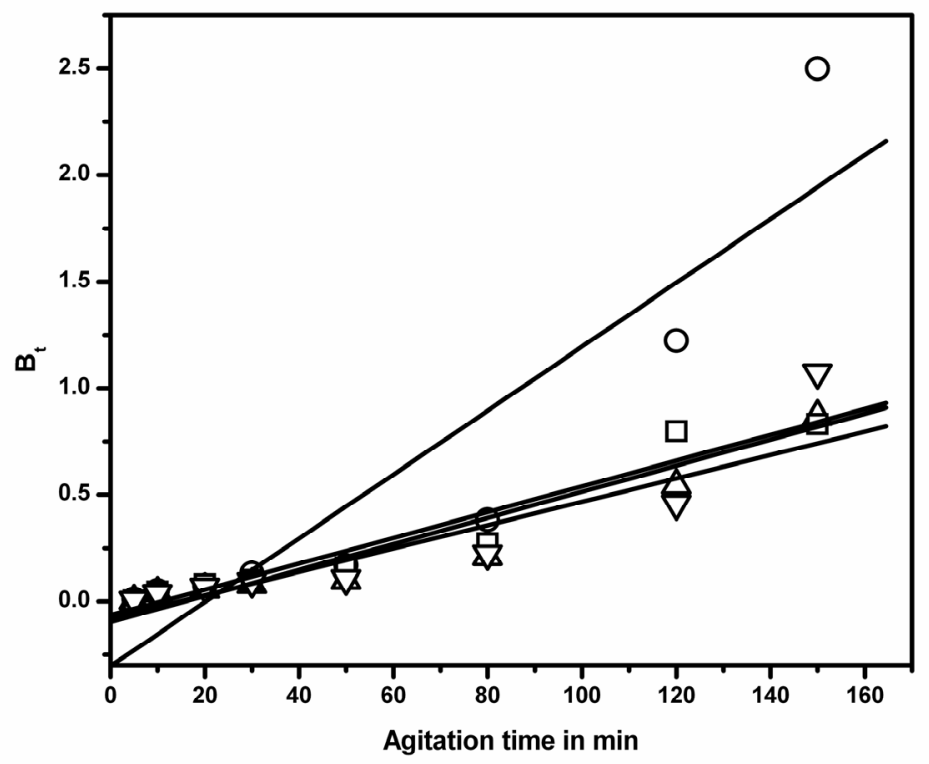

Figure 11. Effect of Concentration of Malathion on the Diffusion coefficient.

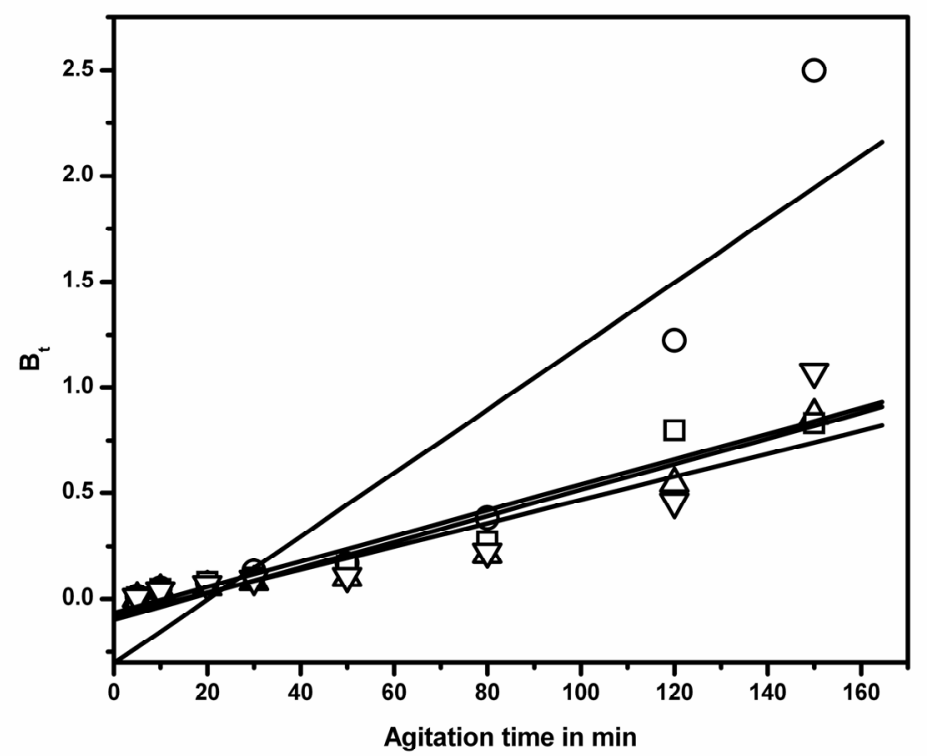

Figure 12 .Effect of Concentration of Malathion on the Diffusion coefficient. 